Khlifi Khaoula, Amira Haddouk, Vítor Monteiro, Joao L. Afonso, Mechergui Hfaiedh

"Modeling and Thermal Energy Management in Smart Homes,"

EAI SESC International Conference on Sustainable Energy for Smart Cities, Braga, Portugal, Dec. 2019. 


\title{
Modeling and Thermal Energy Management in Smart
}

\section{Homes}

\author{
Khlifi Khaoula ${ }^{1}$, Amira Haddouk ${ }^{1}$, Vitor Monteiro ${ }^{2}$, Joao L. Afonso ${ }^{2}$, and \\ Mechergui Hfaiedh \\ ${ }^{1}$ Research Laboratory: LISIER, EcoleNationaleSupérieure des Ingénieurs de \\ Tunis, \\ University of Tunis, Tunisia \\ ${ }^{2}$ ALGORITMI Research Centre- University of Minho Guimarães - Portugal \\ Khlifi.kh@hotmail.com, \{amira.haddouk,hfaiedh.mechergui\}@ensit.rnu.tn, \\ \{vitor.monteiro,joao.1.afonso\}@algoritmi.uminho.pt
}

\begin{abstract}
In this paper, it is demonstrated the importance of the information concerning the power flow and the state of a building's thermal system for the management and control of electricity consumption. The proposed approach is evaluated simulating the heating exchange behavior of a configurable base model for an isolated and non-thermally insulated habitat in order to determine the influence of the energy losses on the control system. Based on the results obtained with this study, some improvements were carried-out for the management system of the heating flow by introducing appropriated parameters into the control algorithm.
\end{abstract}

Keywords: Thermal energy management; Smart home; Load control; Modeling.

\section{Introduction}

Nowadays, heating consumption is considered the first lever for energy saving in residential buildings. As particular case, in Tunisia, the abundance of electricity consumption comes mainly from heating and domestic hot water uses whose final demand is $65 \%$ of total consumption. Otherwise, due to economic crisis and ecological concerns, it is always interesting to consume less for paying less. The loads of type thermal comfort, which are heating, ventilation and cooling, represent 
between $30 \%$ and $50 \%$ of residential and service electric energy consumption. This type of loads offers interesting load control possibilities [1]. In fact, the use of buildings thermal inertia allows to relieving these loads for a while without altering occupant comfort. Buildings can also be preheated or precooled in anticipation of constraints on the grid or during periods when the energy price is low [2]. Information on energy flows and system states are necessary for management, exploitation and the distribution of energy resources, where the main information is measured [3]. Another requirement related to the control of loads is the metering and statements transmission. It is also recalled that data collected must be specific with standardized and secure communications [4]. The controllability of a load is defined as his ability to be underpowered, in energy saving mode or turned off for a while in response to an outside call. This signal can be linked to a security or an economic aspect. Therefore, the modeling of a thermal system is necessary to understand his behavior by setting up a set of equations describing relationship between its inputs and outputs so; it becomes possible to simulate its impact on the electricity consumption of heating with a rather fine temporal resolution. We also note that we can check the response of the load subjected to several solicitations such as climate change or thermal losses [5]. This approach can then be defined as a behavioral diagnostic describing the relationship between energy requirement and the total consumption cost. The aim of this work is the simulation of an energy system model based on the state representation to descried its behavior and establish a measurement report. Indeed, we are interested in considering the building as a system that dynamically interacts with a set of climate data while being conditioned by the need of the consumer. To achieve such management, we must first start by structuring the model behavior. The simulation software that will serve is Matlab Simulink, Simscape and Power system.

\section{Modeling and mathematical representation of the components involved in the buildings thermal exchange}

The modeling methods are numerous. The main classification takes place between static and dynamic ones [6]. There is also physical modeling based on fundamental knowledge and physical phenomena that affect the system. There is also the empirical modeling method called «black box», based on the mathematical relations inputs and outputs of the system [7]. In this work, the model will initially have a simple basic structure that will be modified and parameterized as and when required. The goal is to simulate the heat exchange evolution of an insulated or non-insulated room using or not an electric heating.

The overall system state representation is obtained from the combination of the following linear thermal equations. These last allow defining the elements that make up the room in terms of heat transfer and thermal mass. 


\subsection{Model of a wall without insulation}

The linear thermal equation (1) represents the modeling of an ordinary wall:

$$
\frac{\mathrm{dT}_{\omega}}{\mathrm{dt}}=\frac{\mathrm{A}_{\omega}}{\mathrm{C}_{\omega}}\left[\mathrm{U}_{\omega \mathrm{i}}\left(\mathrm{T}_{\mathrm{ai}}-\mathrm{T}_{\omega}\right)+\mathrm{U}_{\omega \mathrm{o}}\left(\mathrm{T}_{\mathrm{ao}}-\mathrm{T}_{\omega}\right)\right]
$$

With $\frac{d T_{\omega}}{d t}$ is the thermal flow of the wall towards inside the house $(J / s), T_{\omega}$ wall temperature $\left({ }^{\circ} \mathrm{C}\right), A_{\omega}$ wall surface $\left(\mathrm{m}^{2}\right), C_{\omega}$ wall thermal capacity $(\mathrm{J} / \mathrm{K}), T_{a i}$ indoor air temperature $\left({ }^{\circ} \mathrm{C}\right), \quad \mathrm{U}_{\omega \mathrm{i}}$ coefficient of thermal transfer inside the wall $\left(\mathrm{W} / \mathrm{m}^{2} . K\right), U_{\omega 0}$ coefficient of thermal transfer outside the wall $\left(\mathrm{W} / \mathrm{m}^{2} . K\right)$ and $T_{a o}$ outside air temperature $\left({ }^{\circ} \mathrm{C}\right)$.

\subsection{Model of a ceiling without insulation}

The ceiling model of a room is given by the following equation:

$$
\frac{\mathrm{dT}_{\mathrm{c}}}{\mathrm{dt}}=\frac{\mathrm{A}_{\mathrm{c}}}{\mathrm{C}_{\mathrm{c}}}\left[\mathrm{U}_{\mathrm{ci}}\left(\mathrm{T}_{\mathrm{ai}}-\mathrm{T}_{\mathrm{c}}\right)+\mathrm{U}_{\mathrm{co}}\left(\mathrm{T}_{\mathrm{ao}}-\mathrm{T}_{\mathrm{c}}\right)\right]
$$

Where $T_{c}$ is the ceiling temperature $\left({ }^{\circ} \mathrm{C}\right), A_{c}$ ceiling surface $\left(m^{2}\right), C_{c}$ ceiling thermal capacity $(\mathrm{J} / \mathrm{K}), U_{c i}$ coefficient of thermal transfer inside the ceiling $\left(\mathrm{W} / \mathrm{m}^{2} . K\right)$ and $U_{c o}$ coefficient of thermal transfer outside the ceiling $\left(\mathrm{W} / \mathrm{m}^{2} . K\right)$.

\subsection{Model of a door without insulation}

In general case, the model of a door takes into account the heat exchange between the temperatures of the two parts that it separates. In our case, the room is considered the simulation house so the heat exchange takes place between that room and the outside air.

$$
\frac{\mathrm{dT}_{\mathrm{d}}}{\mathrm{dt}}=\frac{\mathrm{A}_{\mathrm{d}}}{\mathrm{C}_{\mathrm{d}}}\left[\mathrm{U}_{\mathrm{di}}\left(\mathrm{T}_{\mathrm{ai}}-\mathrm{T}_{\mathrm{d}}\right)+\mathrm{U}_{\mathrm{do}}\left(\mathrm{T}_{\mathrm{ao}}-\mathrm{T}_{\mathrm{d}}\right)\right]
$$

With $T_{d}$ the door temperature $\left({ }^{\circ} \mathrm{C}\right), A_{d}$ door surface $\left(m^{2}\right), C_{d}$ door thermal capacity $(J / K), U_{d i}$ and $U_{d o}$ are respectively the coefficient of thermal transfer inside and outside the door $\left(W / m^{2} . K\right)$. 


\subsection{Model of a window without insulation (single glazing)}

$$
\mathrm{Q}_{\mathrm{g} \text {-air }}=\frac{\mathrm{A}_{\mathrm{g}}}{\mathrm{C}_{\mathrm{g}}}\left[\mathrm{U}_{\mathrm{g}}\left(\mathrm{T}_{\mathrm{ao}}-\mathrm{T}_{\mathrm{ai}}\right)\right]
$$

The ordinary differential equation (4) represents the model of the window where $Q_{g \text {-air }}$ is the thermal flow of the window towards inside the house $(\mathrm{J} / \mathrm{s}), A_{g}$ the window surface $\left(\mathrm{m}^{2}\right)$ and $U_{g}$ the coefficient of window thermal transfer $\left(\mathrm{W} / \mathrm{m}^{2} . K\right)$.

\subsection{Indoor air model (room temperature)}

$$
\frac{\mathrm{dT}_{\mathrm{ai}}}{\mathrm{dt}}=\frac{1}{\mathrm{C}_{\mathrm{a}}}\left[\mathrm{Q}_{\mathrm{e}}+\mathrm{A}_{\omega} \mathrm{U}_{\omega \mathrm{i}}\left(\mathrm{T}_{\omega}-\mathrm{T}_{\mathrm{ai}}\right)+\mathrm{A}_{\mathrm{c}} \mathrm{U}_{\mathrm{ci}}\left(\mathrm{T}_{\mathrm{c}}-\mathrm{T}_{\mathrm{ai}}\right)+\mathrm{A}_{\mathrm{d}} \mathrm{U}_{\mathrm{di}}\left(\mathrm{T}_{\mathrm{d}}-\mathrm{T}_{\mathrm{ai}}\right)+\mathrm{A}_{\mathrm{g}} \mathrm{U}_{\mathrm{g}}\left(\mathrm{T}_{\mathrm{ao}}-\mathrm{T}_{\mathrm{ai}}\right)\right]
$$

Where $C_{a}$ is the thermal air capacity $(J / K)$ and $Q_{e}$ the thermal flow of indoor equipment $(W)$.

The first objective is to give a global vision on the physical aspect of the heat exchange behavior and the impact of insulation on the losses before installing the heater. The mentioned components are characterized by their heat flow and capacity, which will make it possible to determine the heat exchange in the house depending on its surface.

\section{Input parameters}

We consider a surface room of $3 \mathrm{~m}^{2}$ without heating and thermal insulation, which contains a single glazed window. The input parameters are the dimensions of this room, shown in Table 1 . The outside temperature is fixed at $10^{\circ} \mathrm{C}$ and the initial inside temperature, considered as the starting limit condition, is $20^{\circ} \mathrm{C}$.

Table 1. Model room dimensions.

\begin{tabular}{cccccc}
\hline & Width $(\mathrm{m})$ & Length $(\mathrm{m})$ & Height $(\mathrm{m})$ & Surface $\left(\mathrm{m}^{2}\right)$ & Thickness $(\mathrm{cm})$ \\
\hline Room & 3 & 3 & 2.5 & 9 & - \\
Wall & - & 3 & 2.5 & 7.5 & 10 \\
Ceiling & 3 & 3 & 2.5 & 9 & 10 \\
Door & 0.9 & - & 2.15 & 1.935 & 5 \\
Window & 0.6 & - & 1 & 0.6 & $0.4^{*}$ \\
\hline
\end{tabular}

*thickness of a window glass 


\section{Simulations and results}

\subsection{Simulation model 1}

The purpose of this first simulation is to determine how long the outside temperature is reached for two identical houses: house 1 without thermal insulation and house 2 with thermal insulation.

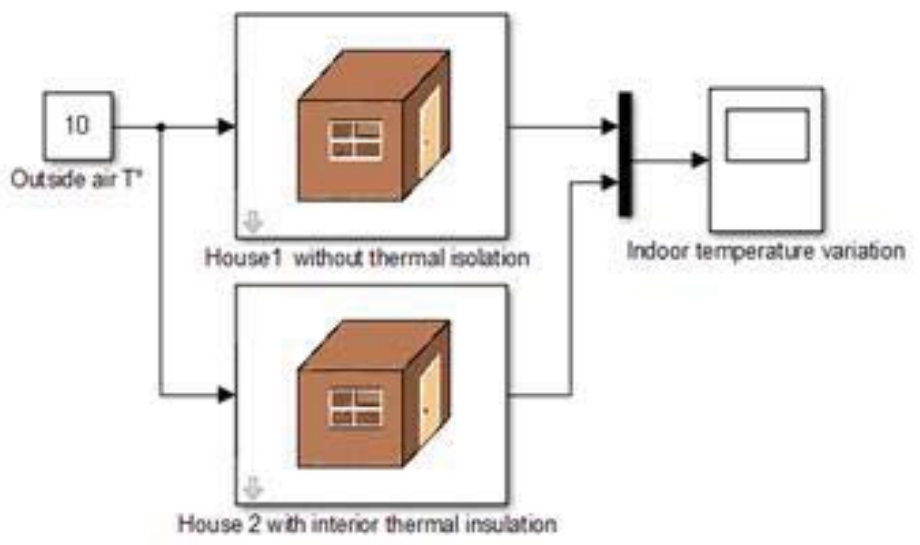

Fig. 1. Thermal system without heating.

Only the heat exchange through the window, the walls and the ceiling is taken into account. The slab and the walls orientations of the house are not considered. 


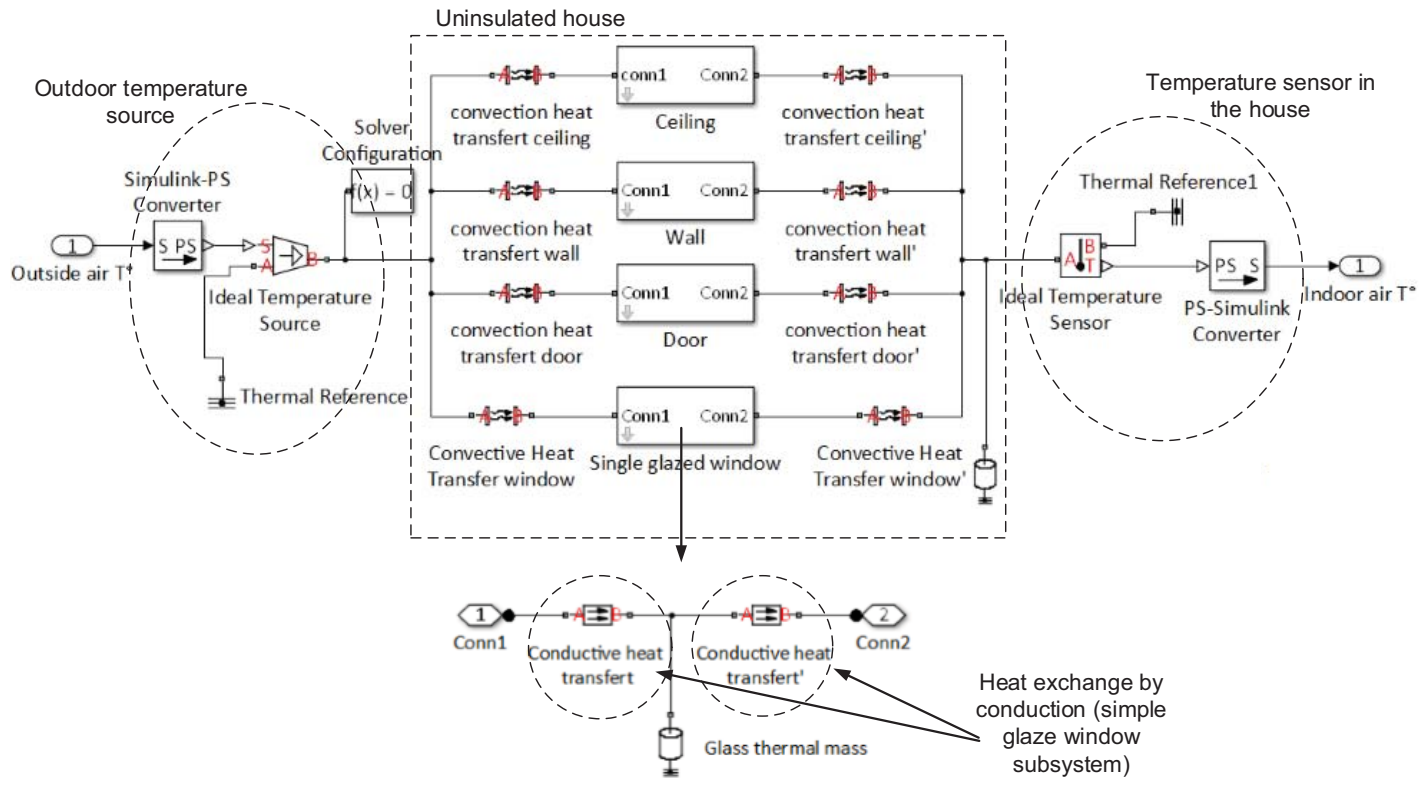

Fig. 2. Subsystems and blocks content.

The global model of house 1, without insulation, is illustrated in Fig. 2 . Referring to equations (1) to (5), the wall, ceiling, door and window blocks, each contain the conduction heat transfer subsystem for transferring heat flow through the house walls. These last are subsequently connected to the convective heat transfer blocks that transfer the heat amount from the outside to the surface materials of the house that we represent their characteristics in Table 2. A temperature sensor is placed inside the room.

Table 2. Thermal properties of the house materials.

\begin{tabular}{cccc}
\hline & $\begin{array}{c}\text { Specific heat } \\
\text { capacity } \\
(\mathrm{J} / \mathrm{kg} \cdot \mathrm{K})\end{array}$ & $\begin{array}{c}\text { Thermal } \\
\text { conductivity } \lambda \\
(\mathrm{W} / \mathrm{m} . \mathrm{K})\end{array}$ & $\begin{array}{c}\text { Density } \rho \\
(\mathrm{kg} / \mathrm{m} 3)\end{array}$ \\
\hline Air & 1004 & 0.2 & 1.2 \\
Brick & 840 & 0.84 & 1500 \\
Glass & 720 & 1.2 & 1530 \\
Oak wood & 2400 & 0.16 & 700 \\
Pain wood & 2227 & 0.15 & 1 \\
\hline
\end{tabular}

In the second house, we inserted a glass wool type interior insulation at the levels of the walls surfaces and the ceiling. The single glazed window is replaced by a double glazed one with argon gas insulation. This gas belongs to the constituents of the earth's atmosphere and to the noble gases family. The choice of these insulators are fixed according to their characteristics in the following Table 3. 
Table 3. Thermal properties of insulation materials.

\begin{tabular}{ccccc}
\hline & $\begin{array}{c}\text { Thickness } \\
(\mathrm{cm})\end{array}$ & $\begin{array}{c}\text { Specific heat } \\
\text { capacity }(\mathrm{J} / \mathrm{kg} \cdot \mathrm{K})\end{array}$ & $\begin{array}{c}\text { Thermal } \\
\text { conductivity } \lambda \\
(\mathrm{W} / \mathrm{m} . \mathrm{K})\end{array}$ & $\begin{array}{c}\text { Density } \rho \\
(\mathrm{kg} / \mathrm{m} 3)\end{array}$ \\
\hline $\begin{array}{c}\text { Glass wool } \\
\text { (wall and ceiling } \\
\text { insulation) }\end{array}$ & 10 & 839 & 0.033 & 25 \\
$\begin{array}{c}\text { Argon } \\
\text { (window insulation) }\end{array}$ & 1.2 & 320 & 0.01772 & 1.783 \\
\hline
\end{tabular}

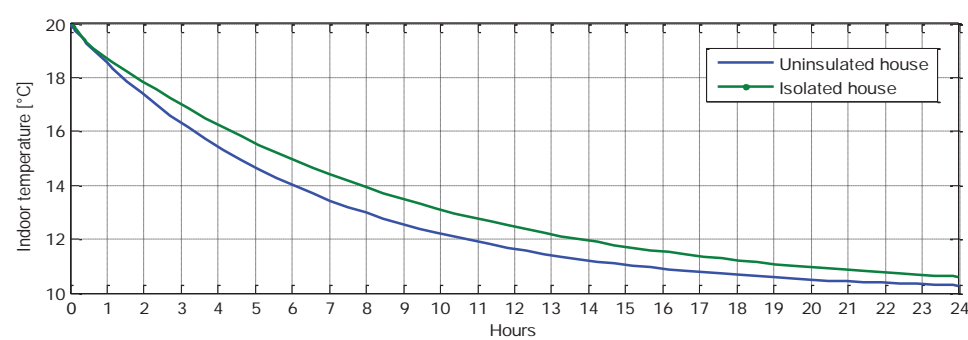

Fig. 3. Simulation results 1 (24 hours).

The comparison of simulation results is represented in Fig. 3. The green curve shows that the room 2, with thermal insulation, reaches the outside temperature set at $10^{\circ} \mathrm{C}$ in over 24 hours illustrating the decrease of the initial temperature. However, the heat is clearly lost faster in the house 1 (blue curve) due to the absence of insulation so losses are obviously much more important. It must then heat in both cases.

\subsection{Simulation model 2: Insulated house with heating / insulated house with heating and regulation}

Let us consider now that the house 1 is thermally insulated and heated by inserting a heat source representing the electric heating power of $200 \mathrm{~W}$. This model is shown in Fig. 4 with the insulating blocks and the heating connected directly to the house thermal mass. 


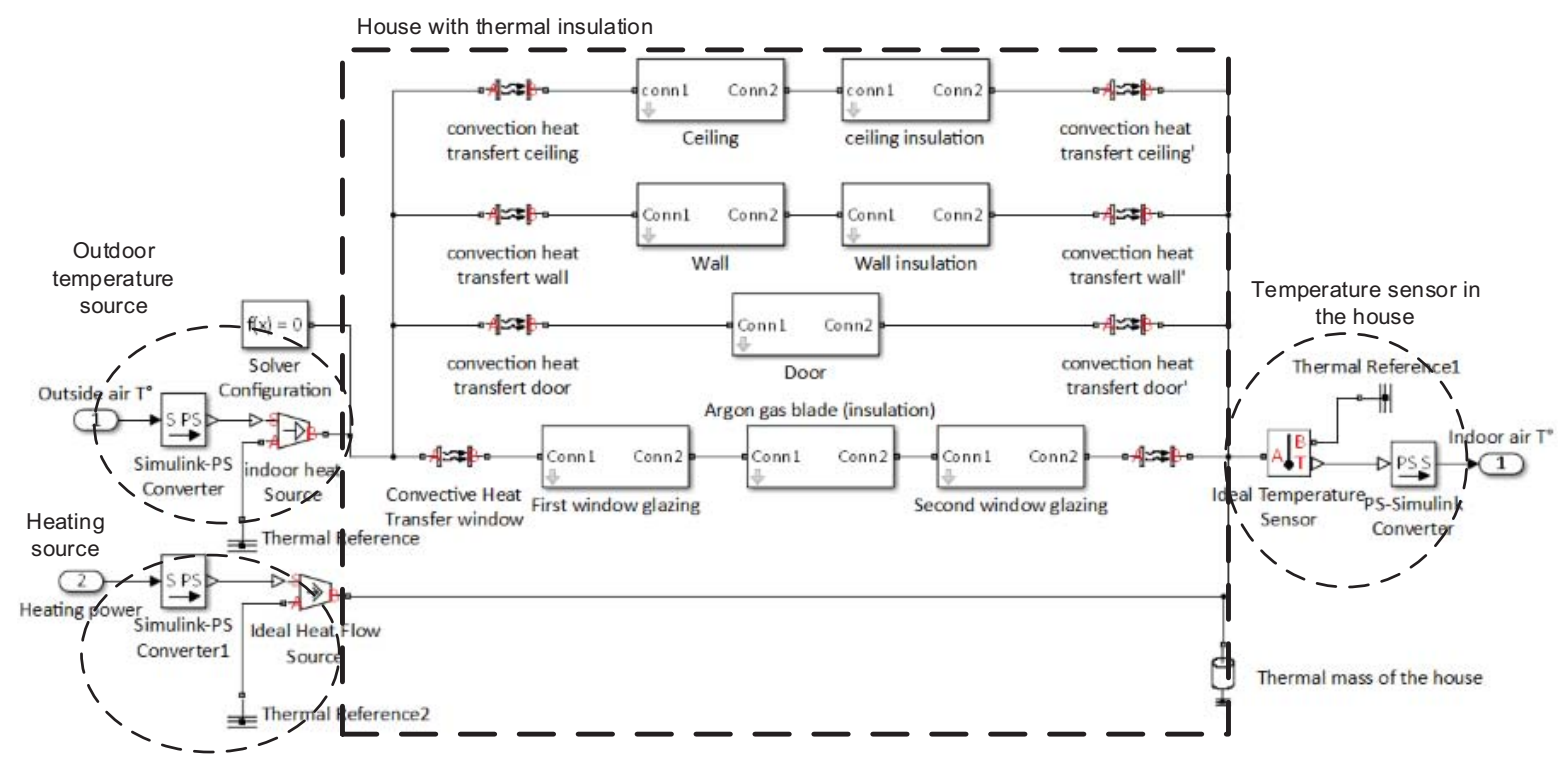

Fig. 4. Subsystems and blocks content.

According to Fig. 5, house 2 has the same heating power but equipped this time with a thermostat. Therefore, the control system now works in a closed loop. The heating is switched on when the temperature is below a set one fixed at $20^{\circ} \mathrm{C}$, then shuts off when the house temperature reaches another set at $22^{\circ} \mathrm{C}$.

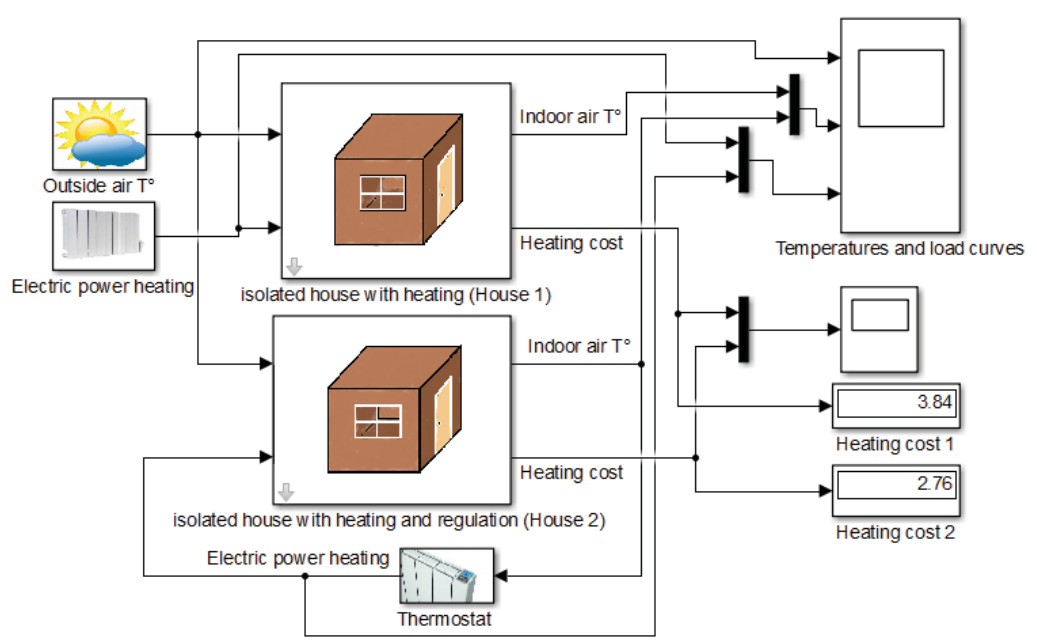

Fig. 5. Thermal system with heating and regulation. 
In order to better understand the studied system and to consider the environmental demands, it is proposed to use the weather data temperature recorded, hour by hour, during the dates 01-01-2019 and 02-01-2019.

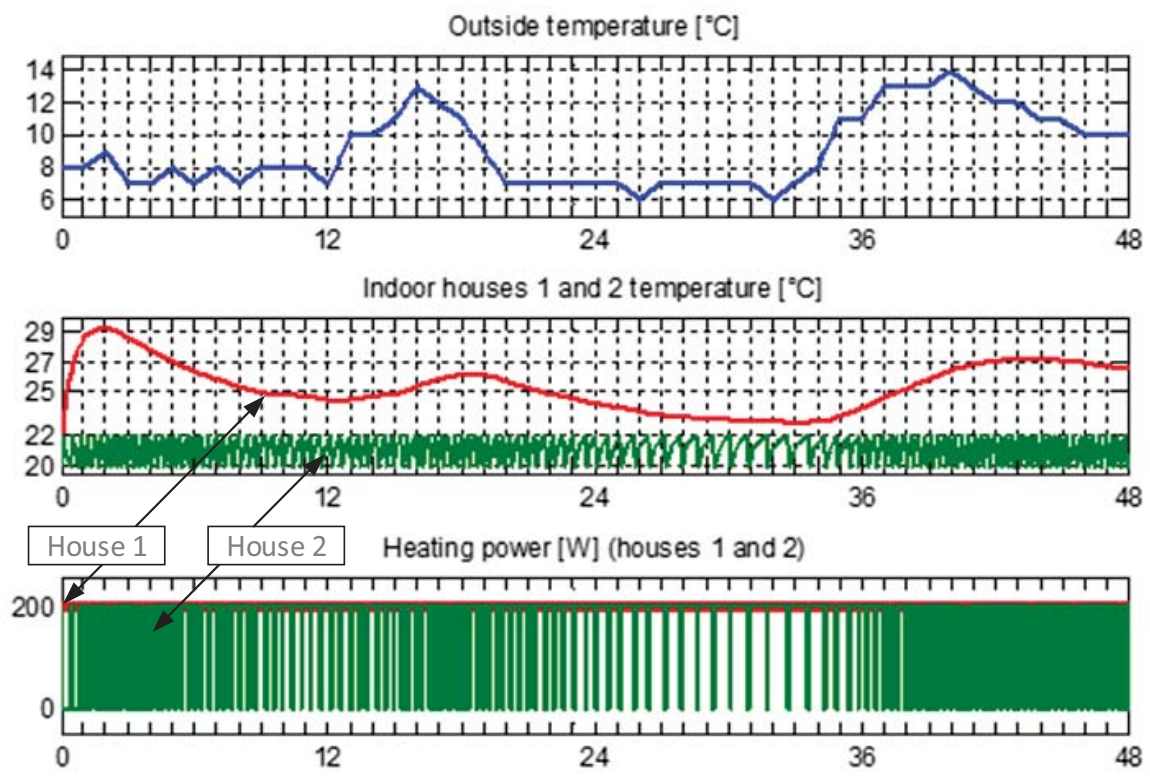

Fig. 6. Simulation results 2 (48 hours).

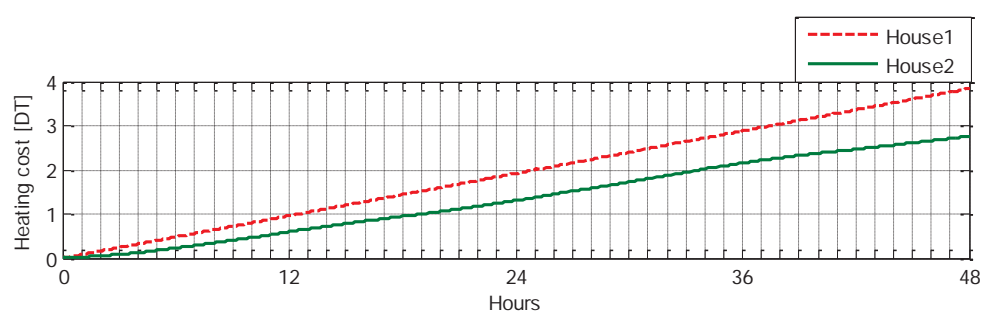

Fig. 7. Power consumption cost curves.

Minimum and maximum outdoor temperatures recorded during these 48 hours are respectively 6 and $14^{\circ} \mathrm{C}$. The heating without regulation of the house 1 operates continuously since it is heating period. The power is then maximum throughout the simulation and it is noted from the red curve of Fig. 6, illustrating the indoor temperatures, that the comfort is missing. Indeed, after two hours of the startup, temperatures reached are very high at about $30^{\circ} \mathrm{C}$ then, vary between 23 and $27^{\circ} \mathrm{C}$. On the other hand, in the case of the house 2 , with heating regulation, the ambient temperature is comfortable and maintained between 20 and $22^{\circ} \mathrm{C}$. We also calculated the cost of heating consumption during these two days for the both houses and we deduct that house 1 records a higher consumption that house 2 with regulation. 
3.3 Simulation model 3: uninsulated house with heating and regulation/ insulated house with heating and regulation

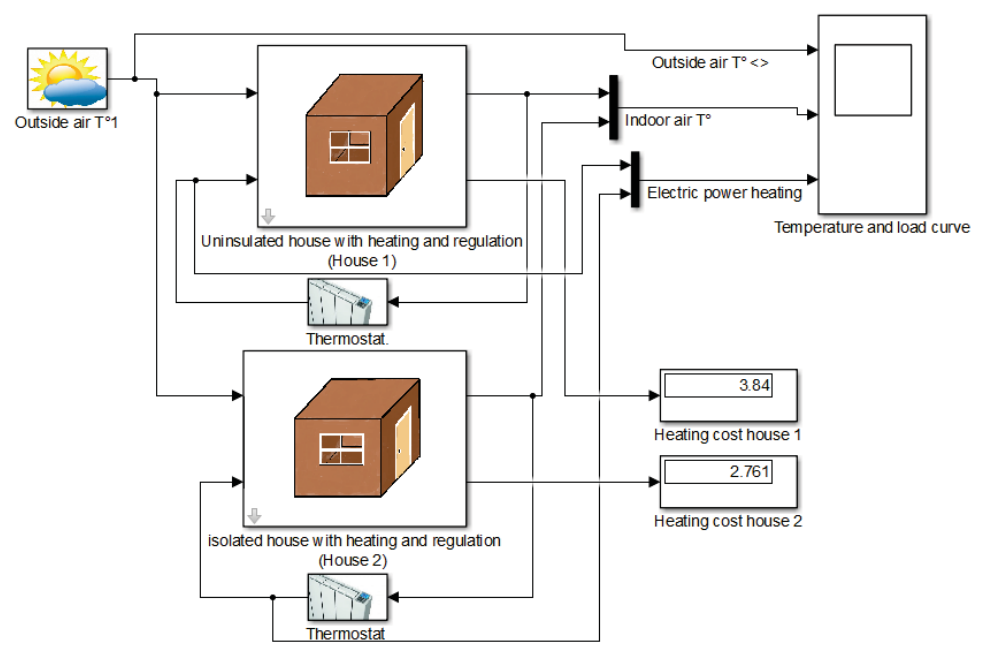

Fig. 8. Thermal system with heating and regulation.

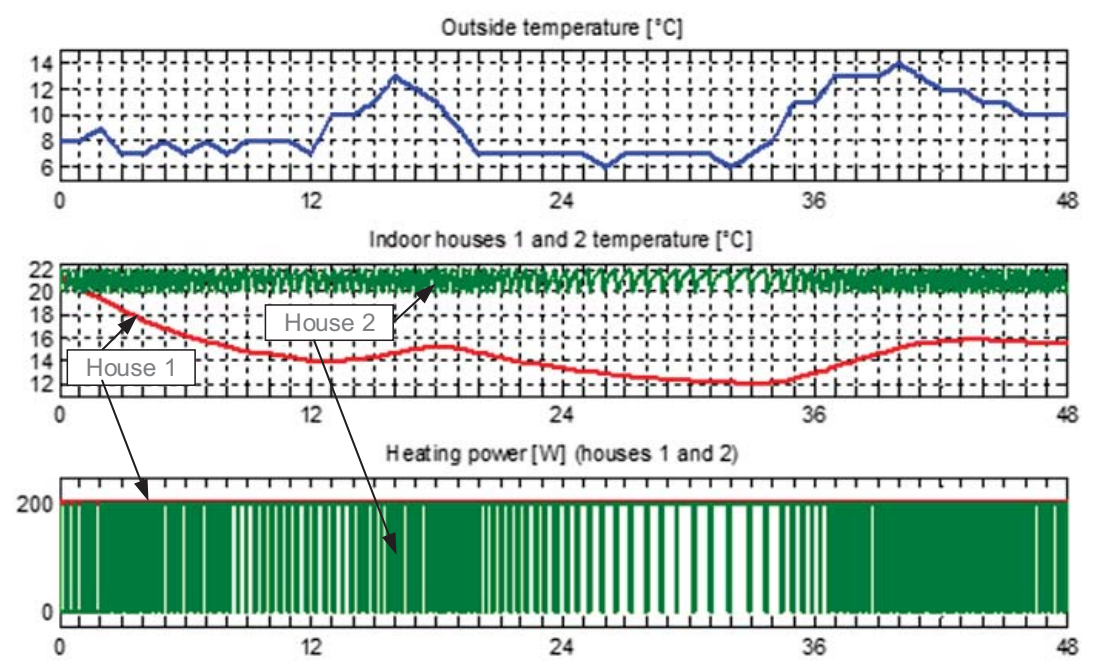

Fig. 9. Simulation results 3 (48 hours).

In this last case, the importance of insulation is put again to the test. Both houses are now equipped with regulated heating. According to the indoor temperature variation curves of Fig. 9, we note that without thermal insulation (red curve), the average house temperature for 48 hours is $16^{\circ} \mathrm{C}$. The heating starts but control stops because 
there are many losses and the ambient temperature does not reach the thermostat set point one while heating remains in permanent operation at full power during all the simulation period. This leads to a consumption cost increase up to 3.84TND for only two days and this amount to the same billing of house 1 in the simulation model 2 without regulation.

\section{Conclusion}

With the work proposed in this paper, it was possible to conclude that without thermal insulation we lose comfort and economy, despite the regulation of heating at ambient temperatures designed to bring occupant comfort. Based on the obtained results, it is also noted that the heating method without isolating the building does not limit the consumption wastage even if we put the heating regulation according to predetermined set temperatures. Indeed, this study shows that the building heating economy is based on, first of all, a priority step which the thermal insulation then the regulation by various means including the intelligent thermostat and the remote control to ensure an efficient load control and realize electric energy economy.

\section{References}

1. Didier Boëda. : Etude de la contribution du pilotage de charges à la fourniture de services aux réseaux électriques. Thesis, Polytechnic institute of Grenoble (2009)

2. François LECLERCQ, Thomas LECLERCQ. : Le système de chauffage et la production d'eau chaude sanitaire. : MATRIciel sa, Energy engeneering, Environment and Special thechniques, University square, 25 - 1348 Louvain-la-Neuve, Bruxelles environment, IBGE -Brussels Institute for environmentalManagement, (2017)

3. Eudeep project, Keynote paper, WP3-S9. : Automation and control issue for DER and technologies involving LTS, (2004)

4. CRISP project. : Distributed Intelligence in Critical Infrastructures for Sustainable Power, ENK8-CT-2002-00673, deliverable D1.2, Market-oriented online supply-demand matching, (2004)

5. N.Saker, M.Petit, J-C.Vannier, J-L.Coullon. : Demand Side Management of Electrical Water Heaters and Evaluation of The Cold Load Pick-Up Characteristics (CLPU), IEEE PES Trondheim PowerTech, pp.1-8, (2011)

6. V. RICHALET. : Caractérisation énergétique des bâtiments sur site. Identification de modèles dynamiques. Méthodes de signature Energétique, Thesis, INPG, (1991)

7. M. GEVERS, A.S. BAZANELLA, X. BOMBOIS, L. MISKOVIC. : Identification and the information matrix: how to get just sufficiently rich, IEEE Transactions on Automatic Control, 54:2828-2840, (2009)

8. M.Amer, A. Namaane, N. K. M'Sirdi. : Smart Home Energy Management Systems Survey, Conférence internationale REDEC, Lebon, Beyrouth, (2014). 